\title{
Liberal Feminism, from Law to Art: The Impact of Feminist Jurisprudence on Feminist Aesthetics
}

\author{
L. RYAN MUSGRAVE
}

This essay explores how early approaches in feminist aesthetics drew on concepts honed in the field of feminist legal theory, especially conceptions of oppression and equality. I argue that by importing these feminist legal concepts, many early feminist accounts of how art is political depended largely on a distinctly liberal version of politics. I offer a critique of liberal feminist aesthetics, indicating ways recent work in the field also turns toward critical feminist aesthetics as an alternative.

Like other twentieth-century social movements, feminism has framed its agenda in terms of the concepts and terminology of classic political liberalism. Given the context of Western liberal democracies, feminists found that by arguing that patriarchal practices actually conflicted with basic commitments of liberalism, they could gain wider impetus for social change of those practices. Other political branches of these movements existed — cultural feminism, radical feminism, multicultural feminism, socialist feminism, Marxist feminism-but liberal feminism was most easily able to tap into large-scale support because of the broad familiarity of liberalism. On the liberal model, equality meant equality before the law: necessary social adjustments could be framed as simply fine-tuning the wheels of justice to run all the more smoothly. Likewise, liberal equality meant democratic representation in a state, and feminists made a convincing case that liberalism required extending civil rights and representation to all.

So after gaining greater social equity on many fronts, feminists turned their attention to art and aesthetics, often employing the same framework of liberalism that had already brought about significant social change. Drawing 
on a liberal understanding of equality, oppression, and democratic representation, they attempted to identify unfair practices in the arts and in aesthetics with feminist legal strategies successfully honed to do the same in the context of education, employment, and market activity. They analyzed the role of art in perpetuating sexist ideologies about female and feminine inferiority; they brought attention to women's lack of access to the means of producing and publicizing art; they examined practices of treating women as the object of art rather than the subject creating art or evaluating it; and they questioned the devaluation of women's creative work to "craft" status. But in bringing sociopolitical concerns to bear on art and aesthetics, feminists found themselves at odds with many of the tenets of mid-to-late twentieth-century aesthetics. From the vantage point of traditional aesthetics, these approaches seemed to be about politics and not about art, and did not translate readily into the traditional framework of the discipline. Traditional aesthetics took its project to be naming universal, ahistorical, and necessary criteria by which judgments about artworks could be considered valid or invalid. Art was thought to be valuable insofar as it transcended daily and empirical concerns, and advanced art was taken to be disinterested, or independent of cultural and historical factors - thus the phrase "art for art's sake." Formal and stylistic facets of artworks were prioritized, and advanced work was thought to operate rationally on a cognitive and unemotive level; works were constantly compared to other works and evaluated as better or worse. The way to do justice to a work was to do close readings of it, pinpointing its formal aspects.

Partly because this traditional project of aesthetics was so resistant to feminism, aesthetics has been one of the last areas of philosophy into which feminism has made inroads. In short, feminism faced the dilemma in aesthetics of trying to articulate forms of oppression and equality with a standard framework of analysis that actively worked against this. Feminists working in aesthetics thus found it necessary to retheorize the connections between aesthetics and politics, demonstrating how they are linked in ways previously unrecognized. This retheorization of the links between aesthetics and politics inaugurated, as Mary Devereaux has put it, "what many thinkers have called a conceptual revolution. Central to that revolution has been a reexamination of autonomous aesthetics" $(1992,165)$. While feminists were not the first to critique autonomous aesthetics, they have constituted enough of a critical mass to foreground these questions in philosophical aesthetics. ${ }^{1}$

My aim here is to explore two related questions: first, the impact feminist jurisprudence has generally had on feminist work in aesthetics; and second, the degree to which feminist conceptions of equity in the arts depended on a distinctly liberal understanding of the aesthetics-politics link. It is my argument that while the creative application of feminist legal strategies has had far-reaching positive effects in the arts and aesthetics, and while it might have even been 
necessary as a first approach, the approach also has its drawbacks. Similarly, I argue that relying mostly on a liberal formulation of oppression and equality in the arts figures these categories too narrowly. To make this case, I first examine key tenets of liberal feminism as it developed in the legal context. I then explore two now-familiar feminist legal approaches: Catharine MacKinnon's harm analysis (see, for example, MacKinnon 1987, 1993). and the arguments of free-speech feminists, often juxtaposed as opposites in First-vs.-FourteenthAmendment debates. Uncovering the aesthetic commitments implicit in each, I consider their combined impact on feminist aesthetics. Because MacKinnon's legal strategies have been more widely recognized as problematic for the arts, I focus on the liberal free-speech arguments that are frequently thought of as a viable, egalitarian antidote in the arts to MacKinnon's approach. Though the approaches are different, I try to show important commonalities between them that should ultimately cause feminists to reject them both as tools for defining oppression and equality in the arts. In conclusion, I stress the importance of attending to the role that law-based concepts play in feminist refigurations of the aesthetics/politics ligature and suggest that recent work in feminist aesthetics has developed partly in response to liberal models being insufficient tools on their own for feminist aesthetics.

It is also important to note, I think, that this project is situated in another developing vein of work in aesthetics: that of aesthetics and law. In a recent article, Brian E. Butler takes stock of three angles of inquiry common to new work in law and aesthetics. Theorists have examined ways in which "art may influence the way law is practiced" (the impact of art on law); ways in which "law might be itself a form of artistic production" (law as art); and ways in which studying legal practices could "help identify aesthetic qualities habitually associated with authority and reason" (exploring ways legal practices lend authority, or "give the law" to, criteria of reasonableness in aesthetics) (2003, 1). Part of what I am suggesting is that feminist approaches (and those of new social movements in aesthetics, generally) add a fourth sort of question to this array: they ask how legal strategies legitimate certain definitions of oppression or equality, or legitimate a certain version of "politics" that affects how we think of politics and aesthetics. Since law is one (some argue it is the main) sociopolitical tool in the Anglo-American context for safeguarding equality, democracy, and justice, this fourth question explicitly explores how aesthetics, sociopolitical, and ethical dimensions interrelate. In this, I think it takes a step not necessarily taken by the other approaches Butler mentions. As feminism finds itself turning again to aesthetics with renewed interest in the politically emancipatory possibilities of the field, this essay is partly a call to pay ongoing attention to the role law-based concepts might play in feminist refigurations of aesthetics/politics connections. 


\section{Models of Equality, from Law to Aesthetics}

\section{From Law ...}

Historically, it makes sense to examine the links between ways that new social movements conceptualized equality through law and equality within the arts. While feminists were developing critiques of traditional Western aesthetics, feminist lawyers and legal theorists had already made strides in changing AngloAmerican patriarchal legal systems. In this way, legal models of oppression and equality recommended themselves to feminists working in aesthetics, particularly liberal feminist approaches that had been so effective in the legal realm. I turn now to examine key tenets of liberal feminism in law, so we can ask how these may have been transposed into the context of art and aesthetics.

\section{A. Key Tenets of Liberal Feminism in Legal Studies}

When developing accounts of women's oppression and strategies for eradicating it, twentieth-century Western feminists found a particularly useful tool in the political lens of liberalism. Liberal feminists argued for women's rightful inclusion in the liberal category of the autonomous individual as the basic social unit, and that women likewise be accorded the individual rights connected to the category. Liberalism emphasized a state gaining its legitimacy through democratic representation in the public arena, so feminists argued that as humans, women were also entitled to such self-representation. The role of the liberal state was to be a neutral and impartial overseer of the public sphere, guarding basic positive rights to civic participation and arbiting disagreements over contracts. Feminists argued that as humans, women also be permitted unfettered access to civic participation, work, and market activity in the public sphere. They drew on liberalism's account of "impartial" law to argue for the sex-blind application of laws and picked up on the thread of liberalism that espoused meritocracy, reasoning that women also should be entitled to the fruits they could gain through their own honest work.

While the liberal state guarantees public civil rights, liberal freedom depends on state non-interference with the private sphere. Liberal feminists argued that women, like men, were entitled to their own pursuits, free of state regulation (a strong argument against patriarchal laws granting men various forms of control over women). The liberal state's function is to maintain tolerance of individual preferences protected as "private"-religious views, political positions, one's aims or projects, one's values overall; it has no grounds for disputing the legitimacy of these for the individual. Wendy Brown's critical assessment of liberalism points out that liberty, on this model, means "acting according to one's desires where the law does not limit or proscribe them. . . . Liberties converge with 
rights insofar as they are individual, instrumental, and articulate boundaries between individuals" $(1995,146)$. On this liberal account, values, like goals, are individual and private; society is understood as what Michael Sandel calls "a plurality of persons, each with his own aims, interests, and conceptions of the good" $(1982,1)$. Alison Jaggar has noted that liberalism understands equality as a form of egalitarianism, with "political institutions that do not subordinate any individual to the will or judgment of another. . . G Given these values, liberals have inferred that the good society should allow each individual the maximum freedom from interference by others" (33). On this model, the root of women's oppression lay in their lack of access to the civic participation enjoyed by men: equality would obtain when women were enfranchised and had fair access to jobs and public pursuits.

Feminists working in legal contexts from the 1960s on had certainly developed other political accounts of oppression and equality besides liberal feminism-approaches such as socialist feminism, radical feminism, cultural feminism, and communitarian feminism come to mind. ${ }^{2}$ But given the preexisting context of liberal democracy, liberal feminism has arguably been the best translation device for convincing the legal system and the wider public that feminist aims could and should be incorporated into existing law. Liberal feminism was able to constitute itself by demanding that classic liberalism make good on its promise of democratic access and equality by including women in civil life, and it has had such success that it has become perhaps the most commonplace or popular understanding of "feminism" in the Anglo-American context. Liberal feminist arguments have been largely responsible for the list of concrete legal gains of women over the last four decades: greater reproductive freedom, pay equity, equality of opportunity in employment and hiring practices, equality in educational contexts, family leave, etc. It would be no surprise, then, if feminist thinking about equality in aesthetics has followed suit, reflecting liberal categories in many of its commitments.

In considering the impact of feminist legal theories on feminist aesthetics broadly, it is useful to examine a common debate between two positions over how equality and images interact - the debate between Fourteenth Amendment and First Amendment feminists. To take even the preliminary step of appealing to law to seek justice and equality is to buy at least partly into liberalism, since liberalism holds it is only through law and rights that basic equality can be maintained. In this limited sense, the entire debate is situated against a liberal backdrop. (Just as one alternate possibility, cultural feminists have argued the futility of expecting law to deliver meaningful equality, calling instead for establishing different criteria through which to promote a more meaningful sort of equality. Such criteria would prioritize nurturance, interconnectedness, intimacy, and care for others, values not espoused by a liberalism committed to categories of normative dualism and the atomistic individual. ${ }^{3}$ That said, 
the sides of the debate then split toward different emphases: First Amendment argument focuses on the "liberty" thread of liberalism, while the Fourteenth Amendment approach appeals to the "equality of opportunity" thread of liberalism. Though I will focus mostly on liberal assumptions of the former, the latter has gained serious feminist support, making it important to consider how each might have ramifications for aesthetics.

\section{B. MacKinnon's Aesthetics: Conservative Realism}

We cannot address aesthetics without considering pornography.

\section{-Catharine MacKinnon, Feminism Unmodified: Discourses on Life and Law}

Legal debates over pornography and hate speech—especially feminist accounts of how verbal and visual representations function as barriers to democratic representation-have ramifications for feminist aesthetics, and Catharine MacKinnon's approach to equality, images, and law must be considered when examining this impact. MacKinnon describes her work as radical feminism and offers it as an alternative to liberal feminism. Along with others, she critiques liberalism as predicated on a model of human experience that is distinctly male, arguing this model cannot lead to any meaningful equality if superimposed on women while retaining this grounding. While I cannot fully consider her entire legal approach here, there is strong debate amongst feminists about its merits and weaknesses. In considering aesthetics, it is important to ask what sort of implicit feminist aesthetic theories have quietly developed within feminist legal remedies based on MacKinnon's work. She has argued that words and images harm women by enacting an oppressive reality of women being denigrated, and by operating as if this was the entire truth of womanhood. On her model, images oppress insofar as they mis-depict the whole personhood of real women and tell a false story about womanhood that further enacts oppressive practices. This is her theory of how pornography functions, as she reads gender and sex directly off of pornography: "Pornography is masturbation material. It is used as sex. It therefore is sex. . . What is real here is not that the materials are pictures, but that they are part of a sex act" $(1993,17)$. We see in this theory a particular assumption about how images (photographs, film, or video) connect with oppression or liberation: through the background conditions in which it was made, and through its expected effects. "Pornography does not leap off the shelf and assault women. Women could, in theory, walk safely past whole warehouses full of it, quietly resting in its jackets. It is what it takes to make it and what happens through its use that are the problem" $(1993,15)$. On MacKinnon's 
analysis, the actual pornographic photograph - the physical object-recedes from the forefront of consideration in favor of analyzing "what it takes to make it" (the conditions behind it) and "its use" (the future effects it produces).

I am not suggesting here that MacKinnon argues for her theories about pornography to be extrapolated wholesale into our concepts or laws about art. But she does directly address the fact that her analysis raises concerns about images other than pornography. "This is not to object to primitiveness or sensuality or subtlety or habituation in communication. Speech conveys more than its literal meaning, and its undertones and nuances must be protected. It is to question the extent to which the First Amendment protects unconscious mental intrusion and physical manipulation, even by pictures and words, particularly when the results are further acted out through aggression and other discrimination" (1993, 16). MacKinnon's legal strategies suggest that what's significant about images is their content, and that the meaning of images can generally be literally read as being about that content. Concerned about how First Amendment principles might be used to justify oppressive social practices, she invokes the equal protection clause of the Fourteenth Amendment as a grounding for legal policies promoting equality. Her brief comments directly on aesthetics condemn the field as one more patriarchal front for oppressive and discriminatory practices. When MacKinnon explicitly mentions aesthetics, she actually hints at it as a root cause of sexism: "Just as aesthetics defines and protects pornography as art, literary criticism defines and protects it as literature, and sexology defines and protects it as sex, the First Amendment defines and protects it as speech. And for the same reasons: political reasons, reasons of sexual politics, reasons of the power of men over women. One wonders which came first, the canon or the pornography" $(1987,4)$. We see here a suspicion that the criteria by which traditional literary criticism and aesthetics have historically claimed to evaluate art-neutral, apolitical, and universal formal criteria — are in fact political through and through. And not just partly political: on MacKinnon's claim, they are purely political, nothing but political power exerting itself through empty claims of formal or stylistic intricacy. So on her model, to attend to such features of a work is an oppressive move: anyone interested in equality regarding images should examine the conditions under which the work was made, should name the literal content of the work, and should ensure that the work authentically depicts what it shows. ${ }^{4}$ MacKinnon's model suggests that a liberating feminist antidote to pornography would be for women themselves to author authentic and realistic depictions to counter distorted ones of pornography.

The "odd bedfellows" phenomenon of antiporn feminists finding themselves in unexpected alliance with conservative religious factions has frequently been noted, but I want to suggest that one area of agreement between the two camps seems to be their joint dependency on a conservative aesthetics. MacKinnon taps into a particular conception of how images work, a version of realism familiar to political conservatives. The conservative view of art largely under- 
stands art's business to be the mimetic re-presentation or copying of some sort of realistic picture or scene, done with a lesser or greater degree of technical proficiency. This conservative understanding of art fueled U.S. suspicion in the Teens, Twenties, and Thirties of modern art as degenerate or un-American; it has arisen in recent outrage against Robert Mapplethorpe, feminist art, rap, and Chris Ofili. Rather than being an hermeneutic suspicion, this one is similar to the suspicion at the heart of libertarianism: namely, the view that any value promoted by a state would have to be someone's value, so the state ought not be in the business of promoting any one value, lest it try to enforce one particular set of values over the many. In the realm of visual images, this conservative aesthetic often depends on construing an image as a stable symbol or sign, such that an image is a literal reference to reality. In the infamous case of the Mapplethorpe Cincinnati trial, the conservative claim was made that Mapplethorpe's nudes are not art because they are photographs that show and deliver the "real"- framed, in this case, as real homosexuality (since that term, too, is understood as a stable referent, a fixed identity relating to specific sexual acts). The call made here is often for protection of community values, operating with the conviction that these artworks are in fact messages with predictable effects. The conservative approach also often assumes a spectator who is either passive or easily manipulated: children are often mentioned here as a litmus test, the conviction being that if images are not fit for children, they ought not to be in the public realm.

As long as artworks remained content-focused, they could be literally understood as grounded in an unproblematic mimetic function of redelivering reality. These parameters constitute what I'll call conservative realism: the notion that what's significant about artworks is their content; that this content is generally understood as re-delivering something real; and that the meaning of an artwork can be literally read as being about that real something. MacKinnon gets several things right. Politics are certainly at play in canon decisions; speech and images that sometimes seem free-floating and for their own sake do have systems of production behind them and effects to which they contribute. Appeals to aesthetic autonomy or "art for its own sake" have been moves often made by patriarchal and racist systems to occlude sexism and racism at work in art production, consumption, and evaluation. But the mistake of conservative realism, of course, is that it understands artworks as more or less like pre-scripted commodities, delivering a literal reality with some creative twist applied. Just as we expect our consumer products to deliver their particular usefulness, conservative realism often expects its fixed and stable reality to be delivered in a straightforward and pleasing way. Pornography lies, according to MacKinnon: truthful images, ones literally readable and authentic, would counter this.

MacKinnon's political analysis overall is far different from conservative approaches, and is more sophisticated than her comments on aesthetic value alone indicate. But many feminists continue to critique what Wendy Brown 
calls "MacKinnon's insistence that women are entirely the products of men's construction and her ontologically contradictory project of developing a jurisprudence based on 'an account of the world from women's point of view' . . . [her] theory in a Marxist modality without history and without dialectics is conservative insofar as it becomes hermeneutically and ontologically positivist." $(1995,94)$. The positivist understanding of 'women's point of view' MacKinnon espouses has been critiqued, but I think it is important to note that a positivist understanding of artworks - and of the two in tandem-operates in her work as well. On this model, art is just images of something, and what images mean and signify is fixed. The physical object drops out of consideration, and the focus becomes background conditions of the artist and future effects that will be caused by the clear content of the work. Writer Jeanette Winterson critiques this sort of a positivist understanding when she points to "the multitude of so-called realists, many making money out of print, who want art to be as small as they are. For them, art is a copying machine busily copying themselves. They like the documentary version, the "life as it is lived"' $(1996,149)$. Instead, Winterson suggests a different sort of ontology of art: "Art is for us a reality beyond now. An imaginative reality that we need. The reality of art is the reality of the imagination. The reality of art is not the reality of experience" [italics mine] $(1996,148)$.

\section{Liberal Aesthetics}

Domination has its own aesthetics, and democratic domination has its democratic aesthetics.

—-Herbert Marcuse, One Dimensional Man

MacKinnon's Fourteenth Amendment approach is often answered by feminists countering with the First Amendment, calling for "more free speech." They argue that what equality requires is more expression rather than more regulation, and that any constrictions placed on free speech and expression risk especially limiting the liberty of women. Though the possible impact on the arts of MacKinnon's positions have been noted, I am suggesting this side of the debate has perhaps larger ramifications for aesthetics, though not as obviously. The argument here is for a democratization of civil rights: the more widely such basic rights like the right to self-expression can be disseminated amongst people, the better. To do this permits women the maximum liberties promised by liberalism, especially in the areas of speech and expression considered so necessary for democratic self-representation. On this feminist angle, women are autonomous individual agents who must be accorded formal equality before the neutral overseers of law and state. Equality would exist when women are equipped with rights and with the chance to pursue their private aims and values. 
This second common feminist position reads artworks as politically significant insofar as they are "free expression," comparable to a citizen exercising their uncoerced voting rights to political self-expression. The aesthetic import of this position has remained largely unexamined, but I suggest it relies on something like a liberal aesthetic that values artworks as equally valuable expressions, much like all votes. Liberal feminist aesthetics, likewise, encourages a wide range of creative work by women, focusing on gaining their inclusion into traditional rubrics of museums and canons. Though this liberal feminist aesthetic may be a partial improvement over the conservative aesthetic approach, it offers little means for evaluating better vs. worse artworks, less complex vs. more complex ones, and little way to appreciate the distinctively artistic sort of labor that went into a work.

Flashing back to the Mapplethorpe trial and recent debates, First Amendment feminists answer back to Fourteenth Amendment concerns that, whatever the possible effects of artworks, art is self-expression and cannot be regulated by a liberal state. Indeed, the job of a liberal state is to tolerate such self-expression and to accommodate diversity within it. So with this liberal aesthetic, a positivist move happens similar to that occurring in MacKinnon's conservative aesthetic: art becomes flattened into instances of self-expression we should celebrate in order to be inclusive, straightforward expressions of either one's individual experience or one's identity as a member of an historically disenfranchised group. In comparison to the conservative realism of MacKinnon's position, liberal aesthetics seems to depend on a sort of liberal realism - that again, what art signifies or means is fixed as self-expression. And if art is self expression, liberal equality comes through public toleration: because all artworks are posited as equally valuable on this model, we are left with espousing aesthetic relativism, on the liberal account. Both conservative and liberal versions of realism focus on the content of artworks, naming this in a positivistic way, and emphasize emotive aspects of the work. Cognitive aspects drop out of consideration, as does attention to formal and stylistic dimensions of the work. We have, then, two feminist accounts of how images can be political—how they are tied up in oppression and equality. I want now to consider early strategies of feminist aesthetics, to ask about how these two accounts played a role.

\section{II. . . . To Aesthetics}

\section{A. Left/Progressive Suspicions about Aesthetics}

Suspicions about aesthetics have, perhaps surprisingly, come from both ends of the political spectrum. Conservative political distrust of aesthetics has been especially visible when cases of avant-garde art have gained public attention, usually voiced as a claim that aesthetics is only a fancy term for politics, dressed 
up in a lot of terminology and talk about form, color, and composition. Many on the right, that is, suspect art and aesthetics of being thoroughly political, and it is this point on which I suggested above that MacKinnon and conservatives agree. What has received less consideration, however, are left/progressive political suspicions about aesthetics. I consider this because I think it has led a number of people committed to leftist or progressive politics to settle for liberal aesthetics as an adequately emancipatory approach. Art historian and critic Benjamin Buchloh and others have documented during the twentieth century "a leftist prejudice against any form of aesthetic deviance and transgression that did not comply with the prescribed patterns of political models of critique and theoretical transformation" (2000, xxvi). In their introduction to the recent collection Differential Aesthetics: Art Practices, Philosophy and Feminist Understandings, Penny Florence and Nicola Foster also address this: "The idea, variously expressed on the Left, that the aesthetic is a category that is inherently rightist must have the entire range of persons from the conservative to those of repressive or fascist bent laughing all the way to the arms bank" $(2000,3)$. Philosopher Christine Battersby has also noted the phenomenon, especially in reference to British theorists: "Rejecting notions of objectivity along with those of impartiality, analytic philosophers on the British left have tended to stress that the notion of an aesthetic quality is itself an ideological construction. At its most extreme, this position is transmuted into one that insists that the very category of 'art' is itself oppressive of the working classes" (1991, 32).

So there exists also amongst progressive political movements the sense, as artist Adrian Piper puts it, that "we avoid our own gut responses to the pervasive political issues raised by art, by talking about form and color instead" $(1995,237)$. Again remembering the Mapplethorpe Cincinnati trial, the defense took great pains to have art historian witnesses show how Mapplethorpe's controversial images were art rather than pornography because they were really stylistically and compositionally just like his images of flowers-as if this were the full meaning of the work, and the sole appropriate criteria for evaluating the work. In short, many on the political left have suspected aesthetics of not being political enough, and have been unsatisfied with autonomous aesthetics and its focus on art-for-art's sake and on disinterestedness.

\section{B. Early Strategies in Feminist Aesthetics, or:}

"Why do FEMINISTS STILl SPEND SO MUCH TIME TALKING ABOUT ARTISTS AND THEIR OBJECTS?"

Many feminists doing early work in aesthetics agreed with Piper's view that evaluating art via formal criteria was oppressive, so they targeted the formalist and cognitivist components of traditional aesthetics. The main strategies of early feminist work in aesthetics may be well-known to many by now, but a few 
key ones warrant a quick look to inquire about possible liberal underpinnings. Early feminist strategies in aesthetics thus focused on identifying and deconstructing the main story told in the discipline. As is well known, The question "where have the women been" received its most prominent treatment from the perspective of art history, inaugurated by Linda Nochlin's famous 1971 query "Why Have There Been No Great Women Artists?" Along with the project of historical reclamation, Nochlin argued that the answer to her question "lies not in women's lack of artistic talent compared to men, but in their comparative lack of encouragement and in the absence of opportunities to acquire the knowledge and skills to produce art like men" (Silvers 1998, 162). By the 1980s, feminists had identified contributions by women previously ignored by the canon and were moving on to consider the mechanisms of exclusion, the criteria by which women's contributions had been shunted off as "low." The traditional aesthetic project of evaluating artworks on the basis of formal innovation was discarded as too patriarchal: art historian Griselda Pollock suggested in 1988 that "feminist art history has to reject ... evaluative criticism and stop merely juggling the aesthetic criteria for appreciating art. Instead it should concentrate on historical forms of explanation for women's artistic production" (1988, 27). Feminists countered the abstract formalism of traditional aesthetics and its focus on examining discrete artworks: as Karen Edis Barzman put it, "The question is: why do feminists still spend so much time talking about artists and their objects?" (1994, 327). Feminists (and other liberation movement theorists) developed what has been broadly called a "politics of representation" approach, which looked not at the art object but at the background contexts and sociopolitical dynamics behind processes of evaluation. This "access analysis" is the task of the Guerrilla Girls when they count the numbers of women across the artworld and the percentages of museum budgets spent on their work.

Another strategy of the politics of representation approach has been the aim to clearly identify a female artistic identity in order to then celebrate this. As recently as 1998, in describing "the current feminist program" in aesthetics, Anita Silvers argues that any urge ". . for assimilation is precisely not the conclusion the women's movement has striven to reach. The prize on which the collective eyes of progressive women are fixed is the recognition of an artistic identity that pertains to their sex or gender. Feminists seek to prevail over the heretofore unchallenged authority the artworld affords to practices preferred by men. To advance recognition of both women's personal and their group identities in the arts and culture, they have devised a variety of well-publicized strategies that promote women's artistic preferences and practices" $(1998,162)$. This strategy is sometimes referred to as a quest for a feminine aesthetic rather than a feminist one, and, on the level of engaging artworks or texts, as gynocriticism. It has been called an identity politics approach to art, as it suggests a distinctive female creative identity either biologically natural or socially normalized. Many 
have described it as a feminine aesthetic that prioritizes feeling over intellect and proceeds, as Silvers characterizes it, by "embracing rather than abstracting from the subject" $(1998,163)$. Some versions conceive of female artistic identity as natural; others conceive of it as socially constructed. The results this approach delivered were hugely important for the feminist movement: practical effects included further erosion of the art/craft split and a growing recognition of the gendered assumptions behind this dichotomy and the dismissal of women's work as mere craft. As Silvers points out, this approach also "carried domestic objects like quilts onto museum walls," bringing concerns and objects common to the empirical world into the institutions of art and thereby furthering institutional change $(1998,162)$. This shift in focus encouraged women to express themselves artistically in a way that they hadn't before. It also encouraged art historians and critics to turn their attention to art produced by women. In this way, early feminist work in aesthetics worked to dispel the old myths: that women had little interest in or talent for art.

Debates also arose over whether or not to depict the female bodily form: some feminists thought the female figure had been overused, colonized, exhausted, and too symbolically loaded to be recouped for feminist purposes. From this angle, an authentic feminist approach would avoid using any such image. Other feminist theorists have suggested that this iconic image is the most fitting one for feminist artists to work with, that an authentic feminist approach would specifically require reinterpreting and redepicting the female form. But underwriting both the talk of a "feminine aesthetic" and the debates about depicting the female figure is the concept of a stable referent, either a natural or a socially constructed female reality that much prior art practice got wrong. A certain version of mimesis, then, is at play in feminist politics of representation analyses-the conviction that it is the job of art or creative work to get it right, to show how it "really" is, to come clean of previously incorrect and ideologically weighted images.

\section{The Liberal Bent of Early Feminist Strategies in Aesthetics, and Drawbacks of Liberal Feminist Aesthetics}

Looking back on these strategies, we can see that the liberal feminist project of democratic enfranchisement under the law carried over into feminist work in aesthetics in at least four distinct ways. First came the project to enfranchise women themselves, to increase their access to the means of artistic production most directly_access to art schools in order to learn artistic techniques, to art history, and to the physical materials required. A broader level of production was also at stake here, as women further needed access to dissemination of their work through gallery exhibitions, markets, and critical attention. The second move was to enfranchise women's creative work as serious art, to have 
it recognized as creatively valuable. A third move was to enfranchise women as viewers of art - to recognize that much art had historically assumed a male spectator, and to widen that pool to not only permit but also potentially to assume women as legitimate viewers or engagers of art. Female spectators were thought to be entitled to "equality of opportunity" within an artworld figured as another workplace or public arena.

Lastly, feminists sought to broaden or democratize the range of aesthetic values or aesthetic criteria themselves. The idea here was to artistically enfranchise aspects of artworks historically associated with women and dismissed as "feminine": appeals to emotions, use of physical/bodily materials, and use of stereotypically domestic or use-bound materials. The liberal approach thus meant gaining formal equality, or equality in numbers. Art and aesthetics on the liberal feminist account is liberating in that it is inclusive, like voting-and inclusive of creators, spectators, materials, and individual values (assumed to be self-expressive and personal). Art and aesthetics can be liberating, on this model, by allowing previously disenfranchised persons to represent themselves, and by honoring the aesthetic judgments of individuals as valid without imposing some broad notion of "correct" aesthetic criteria. We can see that the liberal assumption of values and preferences as individual, personal, and deserving of maximum liberty threads through a number of these early feminist approaches. We can also see the artwork itself receding from the forefront of consideration, or considered solely in terms of content analysis with the content presumed as a static referent-especially in the politics of representation approach and in those approaches centered on solidifying a feminine aesthetic and a feminist stance on proper ways to depict women's bodies. To offset the heavy, traditional, tripartite aesthetic focus on artworks themselves, their formal/stylistic properties, and an understanding of art as a mainly cognitive enterprise, feminism adopted as a mainstay an aesthetics that pulled away from these. Strategically refocusing on artistic enfranchisement, on contextual access issues, on content identification with personal experience, and on art as a mainly expressive enterprise constituted a liberal feminist aesthetic.

But what drawbacks, if any, does the liberal bent of feminist work in aesthetics present? One drawback is a tendency to undervalue the art object itself, focusing not on it but on long-ignored contextual factors. The first contextual factor on which feminists focused was, of course, the women directly involved in either the production, mediation, or reception of the artwork. Traditional aesthetics had long focused on the art object as the relevant unit to examine, considering the human creator to be an uninteresting sort of conduit (the doctrine of artistic genius furthered this view). Feminism was effectively combating this, and it sought to move away from what it saw as a traditional fetishizing of the object and the canon of which this was a part. But while including women in the production of art is certainly a step toward some sort of equality, this focus 
risks reducing the artwork to the artist herself, or to an even more specific facet of her: her sex. Her personal history can in this way gain greater attention than her artwork: what obstacles did she overcome in producing it? Is she tapping into and creating from an authentic female experience? Likewise, another cluster of common questions arose when including women as viewers or spectators: what does she value when she engages artworks? As a woman, has she assumed as a possible spectator by the work? As a woman, had she been able to gain a knowledge of art history to enable her to contextualize the work? Both clusters of questions take the person behind or in front of the artwork as more central to aesthetic inquiry than the object or work itself. The liberal aim for sheer inclusion and access pulls attention away from the art object and onto issues of fair management of access to opportunities under law.

As aesthetic attention shifts from the art object to contextual factors, a second drawback is at issue here. Florence and Foster point out this trend in Differential Aesthetics (2000), noting Griselda Pollock's explicit 1980s pull away from treating artworks through "close reading" practices or discussions of evaluative criteria: "the social history approach led Pollock to argue that 'feminist art history has to reject ... . evaluative criticism and stop merely juggling the aesthetic criteria for appreciating art. Instead it should concentrate on historical forms of explanation for women's artistic production' $(1988,27)$. Pollock's work since then evidences a considerable move from this position, but it does exemplify a general shift at that time away from 'the aesthetic' both in feminism and in progressive thinking about art of almost all kinds. (Florence and Foster 2000, 20-21)

We see here a second drawback of liberal approaches. On the liberal model of equality, the state necessarily has no role in personal valuation: all sets of personal values are equally legitimate and tolerated, and the state abdicates any judgment about the quality of these, leaving them to individual autonomy. In the arts, the political urge to fight external imposition of values becomes a rejection of canon-building, and the very process of making evaluations about the quality of the work comes under suspicion. The importance of historical factors shaping the production and reception of the artwork may be tremendously important in assessing its value, but it would also seem imperative to attend to the object in other ways-for example, to explore the sort of formal work the artist did in creating it. Although Pollock's step above of giving "historical forms of explanation for women's artistic production" is important for disputing the universality of traditional criteria of aesthetic evaluation, it also seems true that listing historical factors cannot be the end of what should be an ongoing evaluative process. Though Pollock and others have been right to critique the formalist tendencies of traditional aesthetics and its ignorance or occlusion of contextual factors, a proper feminist approach, in her view, turns away from these questions entirely. 
Part of what Pollock critiques is the way traditional aesthetics has defined itself as separate from and opposite to political investments or issues, so it seems problematic to find in her own argument that a proper feminist approach would focus on politics almost exclusively and exclude aesthetics. This approach, I'm suggesting, merely flips the tables in a reactionary manner, privileging politics where traditional aesthetics had disdained it, but maintaining the firm separation of the two. It has been essential for feminist work to deconstruct and critique the criteria used to evaluate artworks and to point out factors influencing women's artistic production, but this cannot be the final step in discussing criteria of appreciation. Even if many feminists are no longer interested in canon formation, or hold that traditional art history just fetishizes objects and hierarchies, practical questions remain about which works to read, to teach, to recommend - and bases for these choices remain to be articulated.

A third drawback of liberal feminist aesthetics lies in its rejection of the modernist focus on form and its focus on content instead as being of primary importance-specifically, realistic content, or what I named above as a commitment to liberal realism. Connected with this has been an increasing valorization of popular arts, texts, and visual images in which larger numbers of people take pleasure, and the argument increasingly advanced is that these forms of pleasure could be just as aesthetically valuable as aesthetic pleasure gained from fine art. Further, feminists have pointed to the classification of low or popular arts (often based on somatic or emotional components) as feminine, in comparison to high art and cognitive or evaluative responses being characterized as masculine. This has led to many feminists valuing realism, work easily understood that might seem to speak literally and to have an identifiable message. On this model, artworks could be considered politically progressive if their content could be grasped fairly easily by large numbers of people, especially women (in the spirit of a populous aesthetic or a so-called art of the people). Understood this way, progressive art would not be esoteric and would not involve lots of background knowledge of art history and development of form (as the modernists might suggest) so that it could garnish popular and widespread appreciation.

\section{Conclusions: Toward Critical Feminist Aesthetics}

I am not suggesting that early feminist approaches were monolithic, or consisted solely of a liberal approach. But even if a liberal approach was merely a prevalent one, it should caution us against valorizing and depending upon that particular account of how art can be political. I hope to have shown some drawbacks that can result from the liberal focus of some early feminist aesthetics strategies. These certainly addressed some oppressive aspects of the artworld: as Devereaux reminds us, "feminist critics and art historians have been enormously successful in uncovering how artworks often support the interests of those in 
power" $(1992,177)$. But this access-based and value-neutral framework seems to assume a realism in art that eschews formal innovation, and operates as if all that can be learned from art is whatever it reflects of the individual experience it is taken to express. This model also seems to expect the artworld to remain a somewhat neutral overseer, like the liberal state. The artwork is valued here as the individual voice or expression of the artist, valuable as one's vote would be valuable: likewise, one's aesthetic assessment of a work seems figured as the "vote" of a spectator, also worthwhile because as an individual expression of a member of a marginalized group, it deserves liberal tolerance. Discussing the formal qualities of such works seems, on the liberal model, just a front for oppressive practices, as if the route to equality in the artworld would be to treat all works and all aesthetic judgments as having formal equality (much like citizens before the law). On this liberal model, artistic representation is figured similar to political representation of oneself in public: equality in the artworld would seem to demand that we increase numbers of underrepresented groups, confer value on their creative work, and amass a plurality of equally valid criteria by which everyone judges art.

But what sort of oppression is fought here? What version of equality is produced in this way? While applauding increased attention to the numbers of minority artists represented in exhibits and increased attention to their work, Henry Louis Gates, Jr. has suggested that "Because of this curious valorization of the social and polemical functions of black literature, the structure of the black text has been repressed and treated as if it were transparent . . . as if it were invisible, or literal, or a one-dimensional document" $(1984,149)$. He argues against this pigeonholing of black creativity as the price of entry into the literary canon. Barbara Christian has echoed his worry that work by minorities and women will be treated as "identity art" only, suggesting that "our writers will be reduced to illustrations of societal questions or dilemmas, in which people, for the moment, are interested, and will not be valued for their craft, their vision, their work as writers" $(1985,149)$. Gates and Christian, rather than being "neoformalist," are correct in noting the commodification of works by blacks. bell hooks (1995) has also written about this phenomenon, pointing out how this narrow understanding of the significance of black art has sadly been adopted by the persons it was presumed to benefit: "Taking our cues from mainstream white culture, black folks have tended to see art as completely unimportant in the struggle for survival. Art as propaganda was and is acceptable, but not art that was concerned with any old subject, content or form. And black folks who thought there could be some art for art's sake for black people, well, they were seen as being out of the loop, apolitical" (hooks 1995, xii).

Christine Battersby notes the false dichotomy at work here that feminism tends to represent to the feminist aesthetician: "she must either eschew all aesthetic value judgments, or lapse into essentialism and formalism" $(1991,35)$. 
If feminist aesthetics relies mainly on liberal feminist concepts of oppression and equality, it lacks a way to still engage in thoughtful deliberation about the formally innovative or significant imaginative labor that can go into artworks. Liberal underpinnings of early feminist aesthetics are certainly not solely responsible for this anti-formal bent. But since the liberal model understands equality as formal equality through identical treatment under the law, transposing the model into the arts seems to suggest that art can lead to equality only through valuing the artworks of individuals as identically respectable forms of self-expression.

Gates, Christian, and hooks are seeking some way for contextual factors concerning the authors to play some political role toward equality, and also for the labor and craft they have wrought to have political value beyond simplistic self-expression. And since a primary goal of feminism has been to show the value of women's labor, including women's imaginative work with formal components of art, importing this liberal legal framework further risks ignoring the liberating possibilities of formally significant work done by women artists. Feminists still need to distinguish between more and less interesting feminist works, to attend to what Peg Brand (1995) calls "the challenge to distinguish between the differing values of politically acceptable works, for instance, between a variety of quilts celebrating women's lives. Since there is no way to value one over another except by formal properties, the distinction should not be dropped" (1995, 270-71, n. 21). Echoing this concern, Jeanette Winterson (1996) has suggested that what I'm calling the liberal approach leads to state encouragement of "notational life" generally, where "freedom of choice is the catch phrase but streamlined homogeneity is the objective ... If the imaginative life is to be renewed it needs its own coin" (1996, 134-35). She rejects the seemingly liberatory aesthetic relativism of a liberally tolerant approach, suggesting that "It is difficult, when we are surrounded by trivia makers and trivia merchants, all claiming for themselves the power of art, not to fall for the lie that there is no such thing or that it is anything. The smallness of it all is depressing and it is inevitable that we will have to whip out the magnifying glass of our own interests to bring the thing up to size. 'Is it about me?' 'Is it amusing?' 'Is it dirty?' 'What about the sex?' are not aesthetic questions but they are the questions asked by most reviewers most of the time. Unless we set up criteria of judgment that are relevant to it, and not to sociology, entertainment, topicality, etc., we are going to find it harder and harder to know what it is that separates art from everything else" (1996, 119, 111).

While feminists (including Brand herself) have worked to name "other ways" or possible criteria of valuation, more are rejecting a liberal focus on individual artists expressing themselves. Increasingly, work in feminist aesthetics is recognizing these shortcomings and is offering broader accounts of how attention to specific works and their formal properties can be politically valuable. Gates, 
Christian, hooks, Brand, and Devereaux offer an answer to Barzman's query of why "feminists spend so much time talking about ... their objects." This is because neither the artist as imaginative creative person nor the art object itself is entirely captured by or identical with contextual factors or self-expression. A liberal aesthetic model that ignores this is guilty of what Herbert Marcuse $(1964,1969)$ thought was the repressive tolerance implicit in a liberal society, where tolerance of minority viewpoints is the precise mechanism by which such viewpoints are rendered safe, drained of any potential power they might have to produce societal change.

I take Devereaux's work (1992) exploring how some moderate concepts of aesthetic autonomy may be fruitful for feminists to be in this vein. And though Rita Felski (1989) has called for us to move beyond feminist aesthetics, I think the versions she wants to leave behind are ones based on MacKinnon-like conservative approaches to aesthetics and liberal versions content with aesthetic relativism. While Felski declared in the late 1990s that "Feminist aesthetics' does not seem a particularly useful concept for contemporary feminist theorists" $(1998,170)$, it seems that the current proliferation of work seeks to reclaim, to broaden, and to use this concept in a meaningful way. What we see is the field of feminist aesthetics undergoing a trend that has marked feminist theory generally, the historical evolution from "liberal" analyses to "gender" or "cultural" analyses and then to a wide array of analyses. We might productively understand the current stage to be something like a "critical feminist aesthetics," insofar as feminists are building upon gains of previous feminist analyses while critiquing their shortcomings.

Feminist philosophy of the past two decades, in particular, has given increasing attention to aesthetic concerns in areas as diverse as phenomenology, ethics, political theory, and philosophy of law, and the books keep coming: at this writing in 2003, recent feminist contributions in aesthetics include Winterson's Art Objects: Essays on Ecstasy and Effrontery; Brand's collection Beauty Matters (2000); Isobel Armstrong's The Radical Aesthetic (2000); Florence and Foster's collection Differential Aesthetics: Art Practices, Philosophy and Feminist Understandings (2000); Cynthia Freeland's But Is It Art? (2001); and the collection Adorno, Culture and Feminism (O'Neill 1999) to name only a few. These are forging what Armstrong has called "an alternative aesthetic discourse" $(2000,1)$, if we understand the other to be the discourse Gates, Christian, and hook are critiquing. Armstrong (2000) stresses the gains wrought by new social movements' suspicions of aesthetics and art in the service of the already powerful, noting that "these forms of thought have shared a hermeneutics of suspicion. Productive as this hermeneutics has been in so many ways-irrigating intellectual culture with new theory-the concept of the aesthetic has been steadily emptied of content. This movement calls out in its turn the project of rethinking the aesthetic. Such rethinking has become an intellectual neces- 
sity because the politics of the anti-aesthetic rely on deconstructive gestures of exposure that fail to address the democratic and radical potential of aesthetic discourse." (2000, 1-2)

If we are watching the continued development of feminist aesthetics, a key component of it ought to be ongoing examination of how feminism—along with politically progressive movements generally_can build and promote a version of meaningful democratic aesthetics that does not settle for treating art as just individualist, as equivalent to personal style, or as having formal equivalence because all creative self-expressions are emancipatory. I have tried to show that first, while imposing legal models of equality and oppression on the arts made strategic sense for early feminists working in aesthetics, legal strategies risk codifying what might be strengths of art as a critical enterprise that "talks back" to precisely systems such as law. Second, there are problems specific to the imposition of a liberal model, insofar as it colludes with a potentially repressive version of democratic representation rather than feeding what Armstrong calls "the radical potential of aesthetic discourse." It is to the credit of an ongoing feminist movement that analyses offering alternative aesthetics are developing with renewed vigor, seeking to reconcile commitments to aesthetics and what is specific to the arts with democratic aims, but in a critical political vein rather than in a mainly liberal one.

\section{Notes}

Valuable comments on this essay came from Mary Devereaux, Peg Zeglin Brand, and anonymous Hypatia reviewers. The essay was informed and aided by discussions with Nancy Spero, Margaret McLaren, Tim Martell, and the Friends of Minerva discsuion group, especially Scott Rubarth and John Burris.

1. Feminists were not the first to raise these issues. Other twentieth-century aesthetic theorists had explored this area before, notably John Dewey's pragmatist aesthetics in Art as Experience (1934) and Theodor Adorno's Marxist/critical social aesthetics (see Adorno 1997). Although neither directly mentions feminism in the context of aesthetics, their work attempts to integrate (in different ways) aesthetic, sociopolitical, and ethical concerns, and in this shares key concerns with contemporary feminist work in aesthetics. Yet Dewey's and Adorno's aesthetics were treated for most of the twentieth century as oddities outside of traditional aesthetics. While work on aesthetics from new social movement perspectives has not exactly received a warm welcome within the field of traditional aesthetics, feminists have succeeded in bringing these questions to the forefront of discussion in philosophical aesthetics.

2. For an overview of these different feminist approaches in the legal context, see Katharine T. Bartlett and Rosanne Kennedy 1991.

3. Thanks to Margaret McLaren for the reminder that seeing a political framework as distinctly liberal requires contrasting it against competing models. For further 
critique of these particular tenets of liberalism referenced here, see Alison Jaggar 1983.

4. In contrast to MacKinnon's fairly straightforward assumptions about how images are political via their content and effects, Theodor Adorno provides in Aesthetic Theory a Marxist aesthetics that considers how formal and stylistic features of art also have political import. Adorno's account, concerned with political sorts of power distinctive to the arts, is arguably a more nuanced and complex Marxist approach to aesthetics than MacKinnon's.

5. Much of this discussion misses subtleties and real differences between different forms of autonomous aesthetics (see Devereaux 1998).

6. Norma Broude and Mary Garrard's Feminism and Art History (1982) is a milemarker in this important work. Griselda Pollock was also a forerunner in examining the social history of art, and current scholars in the field inevitably cite Old Mistresses: Women, Art, and Ideology (Pollock and Parker 1981) as an influence, along with Pollock's Vision and Difference: Femininity, Feminism and Histories of Art (1988).

\section{REFERENCES}

Adorno, Theodor. 1997. Aesthetic theory. Trans. Robert Hullot-Kentor. Minneapolis: University of Minnesota Press.

Armstrong, Isobel. 2000. The radical aesthetic. Malden, Mass.: Blackwell Press.

Bartlett, Katharine T., and Rosanne Kennedy, eds. 1991. Feminist legal theory: Readings in law and gender. Boulder, Colo.: Westview Press.

Barzman, Karen Edis. 1994. Beyond the canon: Feminism, postmodernism, and the history of art. Journal of Aesthetics and Art Criticism 52 (3): 327-39.

Battersby, Christine. 1991. Situating the aesthetic: A feminist defence. In Thinking beyond traditional aesthetics, ed. Andrew Benjamin and Peter Osborne. London: Institute of Contemporary Art.

Brand, Peg Zeglin. 1995. Revising the aesthetic-nonaesthetic distinction. In Feminism and tradition in aesthetics, ed. Peg Zeglin Brand and Carolyn Korsmeyer. University Park, Pa.: The Pennsylvania State University Press. - ed. 2000. Beauty matters. Bloomington: Indiana University Press.

Broude, Norma, and Mary Garrard. 1982. Feminism and art history: Questioning the litany. New York: Harper \& Row.

Brown, Wendy. 1995. States of injury: Power and freedom in late modernity. Princeton, N.J.: Princeton University Press.

Buchloh, Bemjamin. 2000. Neo-avantgarde and culture industry: Essays on European and American art from 1955-1975. Cambridge: The MIT Press.

Butler, Brian E. 2003. Law as an aesthetic subject. Newsletter of the American Society for Aesthetics, 22 (3): 1-3.

Christian, Barbara. 1985. Black feminist criticism: Perspectives on black women writers. New York: Pergamon Press.

Devereaux, Mary. 1992. The philosophical and political implications of the feminist critique of aesthetic autonomy. In Turning the Century: Feminist theory in the 1990s, ed. Glynis Carr. Bucknell University Press. 
1998. Autonomy, feminist critiques of. In The encyclopedia of aesthetics, ed. Michael Kelly. New York: Oxford University Press.

Dewey, John. 1934. Art as experience. New York: Perigee Books.

Felski, Rita. 1989. Beyond feminist aesthetics: Feminist literature and social change. Cambridge: Harvard University Press.

1998. Critique of feminist aesthetics. In The encyclopedia of aesthetics, ed. Michael Kelly. New York: Oxford University Press.

Florence, Penny, and Nicola Foster, eds. 2000. Differential aesthetics: Art practices, philosophy and feminist understandings. U.K.: Ashgate Publishing.

Freeland, Cynthia. 2001. But is it art? New York: Oxford University Press.

Gates, Jenry Louis, Jr. 1984. Criticism in the jungle. In Black literature and literary theory, ed. Henry Louis Gates, Jr. New York: Methuen Press.

hooks, bell. Art on my mind: Visual politics. New York: New Press.

Jaggar, Alison. 1983. Feminist politics and human nature. Savage, Md.: Rowman \& Littlefield.

MacKinnon, Catharine. 1987. Feminism unmodified: Discourses on life and law. Cambridge: Harvard University Press. 1993. Only Words. Cambridge: Harvard University Press.

Marcuse, Herbert. 1964. One dimensional man. Boston: Beacon Press.

1969. Repressive tolerance. In A Critique of Pure Tolerance. Robert Paul Wolff, Barrington Moore Jr., and Herbert Marcuse. Boston: Beacon Press.

Nochlin, Linda. 1971. Why have there been no great women artists? In Art and sexual politics: Women's liberation, women artists, and art history, ed. Thomas Hess and Elizabeth Baker. New York: MacMillan Publishers.

O’Neill, Maggie, ed. 1999. Adorno, culture, and feminism. London: Sage Press.

Piper, Adrian. 1995. Monologues from "Four intruders plus alarm systems" and "Safe." In Feminism and tradition in aesthetics, ed. Peg Zeglin Brand and Carolyn Korsmeyer. University Park, Pa.: The Pennsylvania State University Press.

Pollock, Griselda. 1988. Vision and difference: Femininity, feminism and histories of art. London: Routledge.

Pollock, Griselda, and Rozsika Parker. 1981. Old mistresses: Women, art, and ideology. London: Routledge.

Sandel, Michael. 1982. Liberalism and the limits of justice. New York: Cambridge University Press.

Silvers, Anita. 1998. Feminism: An overview. In The encyclopedia of aesthetics, ed. Michael Kelly. New York: Oxford University Press.

Winterson, Jeanette. 1996. Art objects: Essays in ecstasy and effrontery. New York: Alfred A. Knopf. 